\title{
Efektivitas Metode Diskusi Dengan Pendekatan Open-Ended Questions untuk Meningkatkan Hasil Belajar Fisika Siswa Kelas X SMA Muhammadiyah Kota Tegal
}

\author{
Nurul Budiarti \\ Program Studi Pendidikan Fisika Universitas Ahmad Dahlan \\ Jl. Dr. Soepomo, SH., Janturan, Warungboto, Umbulharjo, Yogyakarta \\ Surat-e: nurul.diarti@gmail.com
}

\begin{abstract}
Tujuan dari penelitian ini untuk (I) mengetahui hasil belajar fisika menggunakan metode diskusi dengan pendekatan open-ended questions ditinjau dari keterampilan berpikir kritis siswa (2) mengetahui perbedaan efektivitas pembelajaran fisika menggunakan metode diskusi dengan pendekatan open-ended questions dan pembelajaran fisika tanpa menggunakan metode diskusi dengan pendekatan open-ended questions ditinjau dari keterampilan berpikir kritis siswa. Jenis penelitian ini adalah quasi exsperiment dengan desain pretest-posttest control group design. Teknik pengumpulan data yang digunakan adalah dengan tes. Instrumen penelitian yang digunakan adalah RPP, LKS, Soal Pretes dan Posttest. Hasil penelitian ini antara lain (I) hasil belajar fisika menggunakan metode diskusi dengan pendekatan open-ended questions lebih baik daripada hasil belajar fisika tanpa menggunakan metode diskusi dengan pendekatan open-ended questionsditinjau dari keterampilan berpikir kritis siswa. (2) terdapat perbedaan efektivitas dari pembelajaran fisika menggunakan metode diskusi dengan pendekatan open-ended questions dan pembelajaran fisika tanpa menggunakan metode diskusi dengan pendekatan open-ended questionsditinjau dari keterampilan berpikir kritis siswa.
\end{abstract}

Kata kunci: Metode Diskusi, Pendekatan open-ended questions, Hasil Belajar.

\section{Pendahuluan}

Fisika sebagai ilmu dasar memiliki karakteristik yang mencakup bangun ilmu yang terdiri atas fakta, konsep, prinsip, hukum, postulat dan teori serta metodologi keilmuan. Fisika dalam mengkaji objek-objek telaahnya yang berupa benda-benda serta peristiwa-peristiwa alam menggunakan prosedur baku yang biasa disebut metode atau proses ilmiah.

Hasil belajar fisika seharusnya dapat mencerminkan karakteristik keilmuan tersebut. Fisika merupakan mata pelajaran IPA ditujukan untuk mendidik dan melatih siswa agar dapat mengembangkan kompetensi observasi, eksperimentasi serta berpikir dan bersikap ilmiah. Hal ini didasari oleh tujuan utama IPA dan fisika, yakni mengamati, memahami, mengahayati dan memanfaatkan gejala-gejala alam yang melibatkan zat atau materi dan materi.

Kompetensi observasi dan eksperimental ini lebih ditekankan pada melatih kompetensi berpikir dan eksperimental yang mencakup tata laksana percobaan dengan mengenal peralatan yang digunakan dalam pengukuran, baik di dalam laboratoriummaupun di alam sekitar kehidupan siswa[I].
Berdasarkan hasil wawancara dengan ibu Khodijah selaku guru fisika di SMA Muhammadiyah Kota Tegal, pada salah satu materi pembelajaran fisika yaitu gelombang elektromagnetik yang dipelajari siswa kelas $\mathrm{X}$ semester II mempunyai hasil belajar kognitif yang rendah. Dapat dilihat dari nilai rata-rata hasil UTS 70, sedangkan Kriteria Ketuntasan Minimal (KKM) yang telah ditetapkan oleh sekolah yaitu 75.Jadi dapat dikatakan nilai rata-rata siswa tidak mencapai kriteria ketuntasan minimal yang diharapkan.

Rendahnya hasil belajar menunjukan siswa mengalami kesulitan belajar.Salah satu keadaan siswa yang perlu mendapatkan perhatian guru adalah kesulitan di dalam belajar. Kesulitan siswa dalam belajar dapat dipengaruhi oleh beberapa faktor antara lain rendahnya pemahaman siswa tentang konsep dalam mengkaji objek-objek di alam yang berhubungan dengan fisika.

Guru merupakan salah satu faktor terpenting yang dapat menentukan berhasil atau tidaknya siswa dalam belajar fisika. Pemilihan strategi pembelajaran yang tepat akan membantu siswa dalam meningkatkan kemampuan berpikir kritis siswa dalam mengemukakan pendapat di kelas, kesesuian materi yang disampaikan akan membuat siswa jelas dalam memahami materi. Salah satu upaya yang dapat dilakukan oleh guru untuk mengatasi kesulitan 
belajar siswa tersebut adalah menggunakan metode diskusi dengan pendekatanopen-ended questions.

Berdasarkan permasalahan di atas, maka peneliti bermaksud melakukan penelitian yang berjudul "Efektivitas Metode Diskusi Dengan Pendekatan OpenEnded Questions Untuk Meningkatkan Hasil Belajar Fisika pada Siswa kelas X SMA Muhammadiyah Kota Tegal”.

Adapun tujuan dari penelitian ini adalah (I) untuk mengetahui hasil belajar fisika menggunakan metode diskusi dengan pendekatan open-ended questions lebih baik daripada hasil belajar fisika tanpa menggunakan metode diskusi dengan pendekatan open-ended questions ditinjau dari keterampilan berpikir kritis; (2) untuk mengetahui ada atau tidaknya perbedaan efektivitas pembelajaran fisika menggunakan metode diskusi dengan pendekatan open-ended questions dan pembelajaran fisika tanpa menggunakan metode diskusi dengan pendekatan open-ended questions.

\section{Kajian Pustaka}

Dari hasil penelitian yang dilakukan oleh Lailatul Nuraini[2] yang berjudul "Penerapan Model Pembelajaran Open Ended Dengan Pendekatan Active Learning Pada Pembelajaran Fisika Di SMA" menyimpulkan bahwa aktifitas belajar siswa selama mengikuti pembelajaran fisika dengan menggunakan model pembelajaran open ended dengan pendekatan active learning termasuk dalam kategori sedang dengan presentase sebesar 53,95\%. Dan ada pengaruh penerapan model pembelajaran open ended dengan pendekatan active learning terhadap hasil belajar fisika siswa.

Penelitian yang dilakukan oleh Ida Nur Rachmawati[3] yang judul "Peningkatan Sikap Ilmiah dan Hasil Belajar Fisika Melalui Pembelajaran Dengan LKS Open-Ended Disertai Metode Eksperimen Pada Siswa Kelas VIII A SMP Negeri 2 Maesan" menyimpulkan bahwa terdapat peningkatan sikap ilmiah dan hasil belajar pada mata pelajaran fisika.

Penelitian yang dilakukan oleh Laili Muyassaroh[4] yang judul "Efektivitas Pembelajaran Berbasis Masalah Open Ended Problem Pada Materi Listrik Dinamis Terhadap Ketrampilan Berpikir Kritis Siswa” menyimpulkan bahwa pembelajaran berbasis masalah dengan open endedproblem lebih baik dibandingkan dengan model pembelajaran berbasis masalah dengan diskusi terhadap kemampuan berpikir siswa dan keterlaksanaan pembelajaran berbasis masalah dengan open endedproblem tingkat keterlaksanaannya dikategorikan baik sebesar 50\%.

Menurut Becker dan Shimada dalam Takahashi[5], pendekatan open-ended merupakan hasil dari proyek penelitian perkembangan pada metode evaluasi keterampilan dalam pendidikan matematika tingkat tinggi-pemikiran antara tahun I97I dan 1976. Proyek ini bertujuan untuk meningkatkan evaluasi pemikiran siswa keterampilan. Para peneliti menyadari bahwa pelajaran berdasarkan pada pemecahan masalah terbuka memiliki potensi yang kaya untuk meningkatkan pengajaran dan pembelajaran.

Pendekatan open-ended adalah pendekatan pembelajaran menggunakan masalah terbuka, yang memiliki banyak solusi atau strategi dalam penyelesaiannya[5]. Open-Ended Questions adalah pertanyaan terbuka yang dirancang untuk mendorong siswa memberikan jawaban penuh sesuai pengetahuan yang ia miliki. Jawaban yang diungkapkan relatif lebih panjang dibandingkan pertanyaan biasa. Benar salahnya jawaban tergantung pada ketepatan siswa dalam berpikir dan mengungkapkan kalimat jawaban secara jelas. Openended questions yang digunakan dalam pembelajaran fisika memberikan kesempatan bagi siswa untuk menunjukkan pemahaman yang lebih dalam aplikasi penggunaan prinsip-prinsip fisika [6]

Menurut Maqsudah[7] dalam Marina, bentuk pembelajaran dengan pendekatan open-ended yang dapat meningkatkan pemahaman siswa adalah suatu pebelajaran yang menggunakan strategi tiga tahapan yaitu tahap awal, tahap inti dan tahap akhir. Ketiga tahapan tersebut dilaksanakan secara klasikal dan secara kelompok serta kelompok dilengkapi dengan penggunaan Lembar Kerja Siswa (LKS). Secara sistematis bentuk pembelajaran tersebut dapat diuraikan sebagai berikut:

Tahap Awal, merupakan tahap persiapan siswa untuk mengikuti pelajaran. Pada tahap ini guru menjelaskan tujuan pembelajaran, pendekatan atau model serta strategi yang akan dilakukan dalam kegiatan pembelajaran, mengaktifkan kemampuan dasar siswa, mengaitkan materi yang akan dipelajari dengan materi sebelumnya serta mengaitkan motivasi siswa.

Tahap Inti, kegiatan pada tahap ini dibagi dalam tiga aktivitas yaitu aktivitas pengenalan, aktivitas pemahaman, aktivitas pemantapan.

Kegiatan siswa dalam aktivitas pengenalan antara lain membaca dan memahami masalah yang ada pada LKS, menjawab pertanyaan yang diajukan guru serta menyelesaikan masalah dengan mengkonstruksi ide-ide dan pengetahuan dasar yang dimiliki secara individu.

Kegiatan siswa dalam aktivitas pemahaman antara lain menyelesaikan masalah di dalam kelompok dengan melakukan kolaborasi dan pengabungan ide-ide yang diperoleh dari setiap anggota kelompok menuju sebuah kesimpulan yang akan dipresentasikan dan dipertanggungjawabkan di depan kelas. Pada saat diskusi kelas, siswa mencatat hal-hal penting sebagai bahan sharing pendapat.

Pada aktivitas pemantapan kegiatan yang dilakukan siswa adalah memberikan tanggapan dan komentar serta kritikan terhadap jawaban atau kesimpulan dari 
Efektivitas Metode Diskusi Dengan Pendekatan Open-Ended Questions untuk Meningkatkan Hasil Belajar Fisika Siswa Kelas X SMA

Muhammadiyah Kota Tegal

penyelesaian masalah yang telah disampaikan.Selain itu guru mengajukan beberapa pertanyaan untuk memancing respon siswa yang belum muncul.

Tahap Akhir, kegiatan yang dilakukan pada tahap ini adalah guru mengarahkan siswa untuk membuat kesimpulan dari hasil pelajaran. Kegiatan pembelajaran diakhiri dengan melakukan refleksi untuk mengecek pemahaman siswa dengan mengajukan pertanyaan tentang materi yang telah dipelajari.

\section{Metode Penelitian}

Jenis penelitian ini adalah quasi exsperimentdengan menggunakan pretes-posttest control group design. Pada desain penelitian ini menggunakan dua kelas, yaitu kelas eksperimen (A) dan kelas kontrol (B). Desain penelitian ini digambarkan pada Tabel I.

Tabel I. Desain Penelitian

\begin{tabular}{cccc}
\hline Kelas & Pretest & Perlakuan & Posttest \\
\hline A & OI & $\mathrm{X}$ & $\mathrm{O} 2$ \\
$\mathrm{~B}$ & $\mathrm{O} 3$ & - & $\mathrm{O} 4$ \\
\hline
\end{tabular}

Keterangan:

$\mathrm{O}_{\mathrm{I}}$ : tes awal (pretest) sebelum diberi perlakuan,

$\mathrm{O}_{2}$ : tes akhir (posttest) setelah diberi perlakuan,

$\mathrm{O}_{3}$ : tes awal (pretest) sebelum diberi perlakuan,

$\mathrm{O}_{4}$ : tes akhir (posttest) tanpa diberi perlakuan,

$\mathrm{X}_{\mathrm{I}}$ : pembelajaran menggunakan metode diskusi pendekatan open-ended questions,

$\mathrm{X}_{2}$ : pembelajaran menggunakan ceramah.

Teknik pengumpulan data dalam penelitian ini adalah dengan tes. Instrumen yang digunakan adalah RPP, LKS, Soal Pretes dan Posttest. Dalam penelitian ini untuk mengetahui hipotesis yang pertama yaitu mengetahui mana yang lebih baik antara hasil belajar fisikamenggunakan metode diskusi dengan pendekatan open-ended questions dan hasil belajar fisika tanpa menggunakan metode diskusi dengan pendekatan openended questions ditinjau dari keterampilan berpikir kritis, digunakan uji satu pihak.

Untuk menganalisis hasil belajar fisika menggunakan selisih nilai posttest dan pretes. Selisih nilai ini menggunakan persamaan Normalized Gain ( $N$-Gain). Menurut Meltzer dalam Laili[4] indeks gain (gain ternormalisasi) saat dihitung dengan persamaan:

$$
\mathrm{N}-\text { Gain }=\frac{\text { posttest }- \text { pretest }}{\text { skor maksimal }- \text { pretest }}
$$

Untuk mengetahui perbedaan efektivitas dari pembelajaran fisika menggunakan metode diskusi dengan pendekatan open-ended questions dan pembelajaran fisika tanpa menggunakan metode diskusi dengan pendekatan open-ended questions maka data $N$-Gain diberikan uji prasyarat, kemudian dilakukan uji-t data berpasangan.

\section{Hasil Penelitian dan Pembahasan}

Berdasarkan penelitian yang telah dilakukan, diperoleh data hasil belajar siswa. Nilai rata-rata posttest yang diperoleh siswa yang mengikuti pembelajaran dengan metode diskusi dengan pendekatan open-ended questions lebih tinggi yakni 75,70 daripada siswa yang mengikuti pembelajaran tanpa menggunakan metode diskusi dengan pendekatan open-ended questions dengan nilai rata-rata yakni 63,8.

Berdasarkan hasil uji- $t$ satu pihak dengan menggunakan nilai posttest kedua kelas dengan taraf signifikan 5\% dan $\mathrm{dk} 47$ didapatkan nilai thitung $>t_{\text {tabel }}(3,60>2,0 \mathrm{I})$ maka $\mathrm{H}_{0}$ ditolak dan $\mathrm{H}_{a}$ diterima yang artinya hasil belajar fisika menggunakan metode diskusi dengan pendekatan openended questions lebih baik daripada hasil belajar fisika tanpa menggunakan metode diskusi.

Kemudian untuk mengetahui perbedaan efektivitas pembelajaran fisika menggunakan metode diskusi dengan pendekatan open-ended questions dan pembelajaran fisika tanpa menggunakan metode diskusi dilakukan analisa menggunakan data $N$-Gain yang dilihat dari hasil nilai pretes dan posttest kedua kelas. Selanjutnya, uji- $t$ berpasangan yang telah dilakukan dengan taraf signifikan $5 \%$ dan $\mathrm{dk} 47$ diperoleh nilai thitung $>t_{\text {tabel }}(5, \mathrm{I} 7>2,0 \mathrm{I})$, maka $\mathrm{H}_{0}$ ditolak dan $\mathrm{H}_{a}$ diterima yang artinya terdapat perbedaan efektivitas dari pembelajaran fisika menggunakan metode diskusi dengan pendekatan openended questions dan pembelajaran fisika tanpa menggunakan metode diskusi.

Pada penelitian ini, pembelajaran dengan pendekatan open-ended question belum optimal karena siswa belum terbiasa dalam penggunaan pendekatan ini. Pada kegiatan awal pembelajaran dengan pendekatan ini guru menggali kemampuan siswa dengan memberikan pertanyaanpertanyaan yang bertujuan untuk memotivasi siswa dalam pembelajaran. Kegiatan selanjutnya adalah diskusi kelompok untuk mengerjakan LKS yang menggunakan pertanyaan masalah terbuka. Dalam hal ini siswa masih terlihat masih ragu-ragu dalam menjawab LKS menurut pendapat dan cara pikir yang diyakini mereka. Sehingga guru harus menyakinkan siswa bahwa LKS yang mereka kerjakan memang memiliki alternatif jawaban sehingga memiliki solusi yang lebih dari satu. Setelah mengerjakan LKS, masing-masing kelompok mempresentasikan hasil diskusi kelompok. Pada tahap terakhir guru dan siswa bersama-sama menarik kesimpulan.

Kelemahan yang ditemui dalam pembelajaran ini adalah kurang optimalnya pelaksanaan pembelajaran dikarenakan waktu yang terbatas hanya 2 kali pertemuan, dan 
keterbatasan peneliti dalam menyediakan soal-soal berbasis masalah karena tidak semua materi gelombang elekrtomagnetik dapat diselesaikan dengan pendekatan open-ended questions. Karena keterbatasan-keterbatasan tersebut menjadikan pendekatan open-ended questions ini menjadi tidak maksimal dalam pelaksanaannya.

Kesalahan-kesalahan yang sering terjadi antara lain adalah subscript pada kuantitas permeabilitas ruang hampa misalnya harusditulis dengan memakai angka nol bukan dengan huruf "o". Penggunaan prefik asing "non" tidak dipisah dengan kata selanjutnya.

\section{Kesimpulan}

Berdasarkan hasil penelitian dan pembahasan, dapat diperoleh kesimpulan sebagai berikut:

I. Hasil belajar fisikamenggunakan metode diskusi dengan pendekatan open-ended questions lebih baik daripada hasil belajar fisika tanpa menggunakan metode diskusi dengan pendekatan open-ended questionsditinjau dari keterampilan berpikir kritis.

2. Terdapat perbedaan efektivitas dari pembelajaran fisika menggunakan metode diskusi dengan pendekatan open-ended questions dan pembelajaran fisika tanpa menggunakan metode diskusi dengan pendekatan open-ended questions ditinjau dari keterampilan berpikir kritis.

\section{Kepustakaan}

[1] Mundilarto, Kapita Selekta Pendidikan Fisika, Yogyakarta, Universitas Negeri Yogyakarta, 2002

[2] Lailatul Nuraini \& Sri Astutik. Penerapan ModelPembelajaran Open Ended dengan Pendekatan Active Learning pada Pembelajaran Fisika di SMA. Jember: Jurnal Pembelajaran Fisika Vol. I No. I Juni 2012.

[3] Ida. Nur Rachmawati \& Subiki Nuriman, Peningkatan Ilmiah dan Hasil Belajar Fisika Melalui Pembelajaran dengan LKS Open-Ended Questions disertai Metode Eksperimen pada Siswa Kelas VIII A SMP Negeri 2 Maesan. Jember: Jurnal Pendidikan Fisika, Vol. 2 No. 2, September 2013.

[4] Laili Muyassaroh, Efektivitas Pembelajaran Berbasis Maslah dengan Open Ended Problem pada Materi Listrik Dinamis Terhadap Kemampuan Berpikir Kritis Siswa.Skripsi, Yogyakarta, Universitas Sunan Kalijaga Yogyakarta, 2003

[5] Takahashi. A, Commonication As A Process For Students To Learn Mathematical, DePaul University, 2008

[6] Page. James, Physics Open-Ended Questions Support Materials, Learning and Teaching Scodland, 2010

[7] Maria Putriyani. Peningkatan keaktifan dan Prestasi Belajar Matematika Melalui Pendekatan Open Ended Siswa Kelas VI Sekolah Dasar. E-Jurnal Dinas Pendidikan Kota Surabaya, Volume 6. 